\title{
Tobacco rattle virus 29K Movement Protein Is the Elicitor of Extreme and Hypersensitive-like Resistance in Two Cultivars of Solanum tuberosum
}

\author{
Walid Ghazala and Mark Varrelmann \\ University of Göttingen, Department of Crop Sciences, Section Plant Virology, Grisebachstr. 6, 37077 Göttingen, Germany
}

Submitted 7 April 2007. Accepted 29 June 2007.

\begin{abstract}
Leaf infection experiments were used to analyze the host responses of Solanum tuberosum cultivars known to be resistant or susceptible to natural, nematode-mediated infection of tubers and necrosis induction ("spraing") by Tobacco rattle virus (TRV) isolate PpK20 (TRV-PpK20). Extreme and hypersensitive-like resistance (ER and HR-like, respectively) as well as spreading veinal necrosis and systemic infection were observed. Agroinfection of leaves with a DsRedexpressing TRV cDNA clone revealed ER to function on the single-cell level, inhibiting virus replication and possessing the potential to initiate a cell death response. HR-like necrosis was characterized by initial virus replication and cell-tocell movement before the onset of necrosis. Transient agroexpression and Potato virus $X$ (PVX)-mediated expression assays demonstrated that the 29K-PpK20 movement protein (MP) can elicit ER and HR-like cell-death. A TRV isolate, PpO85M, known to overcome the resistance to spraing in plants that are resistant to TRV-PpK20 encoded a variant 29K protein which did not elicit HR in PpK20-HR plants. Our results show that the TRV MP is the elicitor of both ER and HR-like cell-death, that no other TRV-encoded proteins or RNA replication are required for its elicitor activity, and that the host reactions are likely to be controlled by single dominant resistance genes.
\end{abstract}

Additional keywords: avirulence gene, Tobravirus.

Tobacco rattle virus (TRV), genus Tobravirus, is able to infect a broad range of plant species, possesses worldwide distribution, and naturally infects a very large number of plant species (Harrison and Robinson 1978). The virus consists of two RNA species. Genome organization, expression strategy, and variability of strains are summarized by MacFarlane (1999). RNA1 , highly conserved between different isolates, encodes four nonstructural proteins, $134-\mathrm{kDa}$ methyltransferase-helicase and 194-kDa RNA-dependent RNA polymerase (read-through of the $134-\mathrm{kDa}$ open reading frame [ORF]), both of which are believed to be involved in virus replication (Hamilton and Baulcombe 1989). The 29-kDa protein (29K), translated from a subgenomic (sg)RNA, represents the viral movement protein (MP), which also is involved in virus accumulation in Nicotiana tabacum (Ziegler-Graff et al. 1991). The RNA-1 3'-proxi-

Both authors contributed equally to this work.

Corresponding author: Mark Varrelmann; E-mail: mvarrel@gwdg.de

* The $\boldsymbol{e}$-Xtra logo stands for "electronic extra" and indicates that two supplementary figures are available online. mal-encoded $16-\mathrm{kDa}$ cysteine-rich protein $(16 \mathrm{~K})$ functions as a pathogenicity factor and suppressor of RNA silencing (Liu et al. 2002a; Reavy et al. 2004; W. Ghazala and M. Varrelmann, unpublished data). RNA-2, possessing higher variability between isolates than RNA-1, encodes the coat protein (CP) and, in some isolates, other nonstructural proteins responsible for vector transmission by plant-parasitic nematodes in the genera Trichodorus and Paratrichodorus (trichodorids) (Hernández et al. 1997; MacFarlane et al. 1995, 1996; Ploeg et al. 1993). TRV can cause two types of infection: a multiplying infection (M-type), in which both RNAs are present and the virus produces nucleoprotein particles (Cadman and Harrison 1959); and a nonmultiplying infection (NM-type), where only uncapsidated RNA-1 is present and the virus spreads in the complete absence of RNA-2 (MacFarlane 1999).

TRV can induce a disease called "spraing" in potato tubers, which has significant economic implications. Tuber spraing is induced when TRV is transmitted by nematodes to potato roots or tubers (Cadman 1959; Eibner 1959; Robinson 2004; Walkinshaw and Larson 1959) and can be characterized by arcs or flecks of brown, corky tissue present in the tuber flesh or on the surface of infected tubers. These tuber defects may render the tubers unsaleable even at relatively low levels of symptom expression. Chemical control of soilborne vector nematodes is difficult (Harrison and Robinson 1978), does not allow for specific targeting, and, therefore, is prohibited in most countries. Virus testing is not reliable because antisera against CP do not recognize NM-type isolates (Harrison and Robinson 1978). Therefore, in addition to certification schemes in seed potato production and diagnosis based on viral nucleic acid detection, natural virus resistance is the only available and probably the most satisfactory measure for TRV control in the field (Solomon-Blackburn and Barker 2001b; Valkonen 1994).

Barker and Dale (2006) reported that resistance to TRV appears to be controlled by a single resistance gene in some potato genotypes. Resistance assessment in naturally infected soils or in the greenhouse in pots with tested soil inhabiting viruliferous trichodorid nematodes by scoring of tuber symptoms have been described (Dale and Solomon 1988). However, such resistance assessment suffers significantly from the drawback of uneven vector distribution and uneven weather conditions in field trials. It generally is believed that spraing represents a hypersensitive resistance (HR) reaction. This is because only a few plants derived from spraing-affected tubers develop systemic "stem mottle" symptoms (Harrison 1968) and it is difficult to isolate TRV from necrotic tuber tissues (Xenophontos et al. 1998). Although experimental evidence for this idea is lacking, it is notable that susceptible cultivars undergoing compatible interactions with TRV exhibit few if any spraing symp- 
toms in the tuber flesh (Dale et al. 2000; Xenophontos et al. 1998). However, clones or cultivars exist that are thought to react with extreme resistance to attempted infection of tubers with TRV because it is impossible to subsequently reisolate TRV from them (Robinson and Dale 1994). Cv. Russet Burbank, for example, exhibits spraing in response to nematodemediated infection with TRV (Mojtahedi et al. 2001). In contrast, cv. Bintje generally is considered to be resistant to infection (Harrison 1968; Mojtahedi et al. 2001; Xenophontos et al. 1998). Engsbro (1973) suggested that resistance in cv. Bintje is a kind of hypersensitivity, limiting nematode-borne TRV to a few cells at the inoculation site. In addition, cv. Saturna is described as TRV resistant by an unknown mechanism (Barker and Dale 2006; Robinson 2004; Robinson and Dale 1994). However, the experimental proof is missing as to whether spraing represents a hypersensitive host reaction and whether resistance to TRV infection fits into the classical categories of incompatible host resistance response in potato to virus infection. Recently, a mild RNA-1 variant of a TRV M-type isolate (TRV PpO85M) from the Netherlands was found to induce symptoms of spraing disease, when naturally transmitted, in tubers of two out of five resistant cultivars tested, including cv. Bintje but not in of cv. Saturna (Robinson 2004).

According to Cooper and Jones (1983), Hull (2002), Kang et al. (2005), Solomon-Blackburn and Barker (2001a), Valkonen (1994), Valkonen et al. (1996), host responses to virus in plants, including potato, can be categorized in different reactions. A nonhost plant cannot be infected and displays immunity. Infectible hosts may display ER, HR, or susceptibility, including susceptibility to systemic virus movement. Susceptible plants
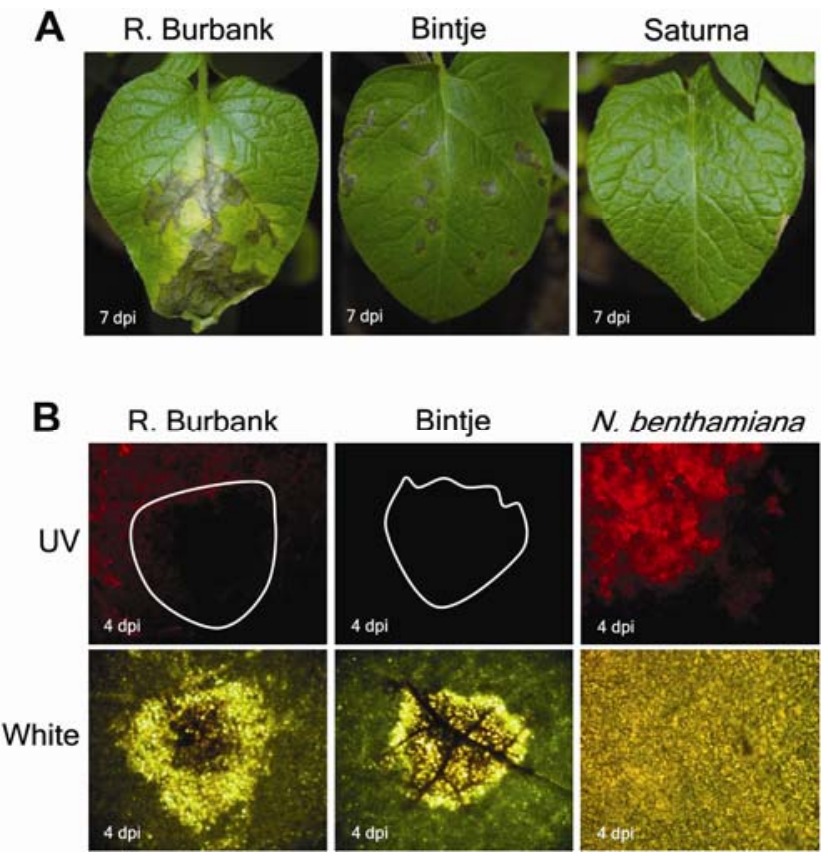

Fig. 1. Mechanical inoculation of Russet Burbank, Bintje, and Saturna leaves with Tobacco rattle virus (TRV)-DsRed (isolate PpK20) infected Nicotiana benthamiana leaf sap. A, Host response at 7 days postinoculation. B, White light microscopy photos and epifluorescence microscopy DsRed-analysis of Russet Burbank and Bintje leaf tissue, respectively, at $\times 25$ magnification in comparison with inoculated $N$. benthamiana leaf tissue at $\times 100$ magnification. White drawing lines indicate the border of the dying and already necrotic leaf area shown in corresponding white-light microscopy photos. Russet Burbank leaves display necrosis (white light) unable to limit the virus movement as indicated by the TRV-encoded DsRed expression outside the developing necrotic area (UV light). Bintje leaves show hypersensitive-like resistance cell death and no virus spread outside the necrotic area, respectively. may show severe disease or they may be tolerant and undergo a latent, symptomless infection. In all cases of ER and HR in potato to virus infection described so far, the resistance is monogenic based on dominant resistance $(R)$ genes (Kang et al. 2005; Solomon-Blackburn and Barker 2001a). In order to activate $R$-gene-mediated defense response, which confines the virus to the point of entry, or at least inhibits the spread of the virus throughout the plant, the invading virus needs to encode a matching avirulence (avr) gene, encoding an elicitor (Hammond-Kosack and Jones 1996; Nimchuk et al. 2003). Several such plant virus genes possessing elicitor functions have been described (Culver 1997; Hull 2002).

However, gaining clear experimental evidence for different resistance reactions in potato against TRV infection is still a challenge. Moreover, it is not known whether the resistance reaction of potato tubers to nematode-mediated infection correlates with resistance to mechanical leaf infection. To characterize these complex TRV-host interactions, we used potato cultivars that show tuber spraing (Mojtahedi et al. 2001), ER, and HR (Robinson 2004) in response to nematode-mediated TRV infection in order to investigate the host response to mechanical leaf inoculation with the TRV isolate PpK20. We detected different host reactions fitting nicely into the categories of "spreading necrosis," $\mathrm{ER}$, and HR, suggesting that spraing and resistance to spraing is not determined by the mode of inoculation, vectored or artificial. This prompted us to identify the viral $a v r$ gene for ER and HR. We were able to show that the RNA-1-encoded 29K MP is responsible for the elicitation of both types of resistance in potato.

\section{RESULTS}

\section{Mechanical and Agrobacterium-mediated leaf inoculation of potato with TRV-PpK20 reveals three classical host-reaction types.}

Potato cvs. Russet Burbank, Bintje, and Saturna were tested for their host reaction to mechanical leaf infection with a DsRed-tagged derivative of TRV isolate PpK20 (TRV-DsRed). TRV PpK20 cDNA clones of RNA-1 (pTRV1) and RNA-2 expressing the DsRed fluorescent marker protein (pTRV2DsRed) instead of $2 b$ and $2 c$ ORFs were agroinoculated and propagated in $N$. benthamiana plants. Leaf sap was used for mechanical inoculation of potato cultivars and $N$. benthamiana. Host responses were monitored at 3, 5, and 7 days postinoculation (dpi) (Fig. 1A; host response shown at $7 \mathrm{dpi}$ ). Leaves of cv. Russet Burbank displayed cell death in response to TRV inoculation, but the necrotic lesions enlarged and surrounding leaf tissue displayed yellowing. The spreading necrosis reached the main leaf vein at $7 \mathrm{dpi}$. The inoculated leaf died a few days after the virus had reached the veins and the infection progressed into noninoculated tissue. Epifluorescence microscopy (FM) examinations revealed RNA-2-encoded DsRed fluorescence in the tissue surrounding the necrotic leaf area (Fig. 1B) and in upper noninoculated leaves at $30 \mathrm{dpi}$ (data not shown). TRV RNA-1 was detectable in both inoculated and noninoculated leaves using reverse-transcriptase polymerase chain reaction (RT-PCR) amplification of the $29 \mathrm{~K}$ gene (Fig. 2) (RNA-2, data not shown). This finding suggests a hypersensitive-like host reaction without the ability to limit the virus spread. The systemically infected leaves of cv. Russet Burbank, however, displayed no necrosis, but only slight mosaic (data not shown). Interestingly, inoculated Bintje leaves displayed necrotic lesions, but these lesions did not enlarge (Fig. 1A; host response shown at $7 \mathrm{dpi}$ ). Replication of RNA-2 was not detected via FM monitoring of DsRed expression outside the necrotic lesions (Fig. 1B). RNA-1 was detected via RT-PCR amplification reproducible only up to $5 \mathrm{dpi}$ in inoculated leaves but never in noninoculated tissue (Fig. 2). There- 
fore, the resistance reaction observed was classified as HR-like necrosis. In contrast, leaves of cv. Saturna did not show any host reaction, nor was TRV infection detected in the inoculated tissue using RT-PCR and FM analysis. This nonhost reaction gave a first indication for the existence of ER in cv. Saturna.

Subsequently, leaf agroinfection of TRV-DsRed (pTRV1 + pTRV2-DsRed) was carried out to confirm the HR-like and spreading necrosis observed using mechanical inoculation. Saturna plants reacting with ER were tested to see whether constitutive expression of viral RNAs could induce a host reaction and whether virus replication (via RNA-2-encoded DsRed detection) would occur at all. To exclude the possibility of interference with the host resistance reaction by Agrobacterium tumefaciens, bacteria harboring an empty binary plant expression plasmid (pBIN61S) were infiltrated at different densities $\left(8 \times 10^{6}\right.$ cells $/ \mathrm{ml}$ [optical density at $600 \mathrm{~nm}\left(\mathrm{OD}_{600}\right)=1$ ] to $1.6 \times 10^{4}$ cells $/ \mathrm{ml}$ in steps of dilution factor 2$)$. An A. tumefaciens suspension with a density of $3.2 \times 10^{4}$ cells $/ \mathrm{ml}$ (corresponding to 250 -fold dilution of $\mathrm{OD}_{600}=1$ ) induced no visible host reaction within $10 \mathrm{dpi}$ and was used for all subsequent infiltrations (data not shown). Additionally, 35S-DsRed was transiently agroexpressed in leaf tissue of all three cultivars and DsRed expression was detectable even at $10 \mathrm{dpi}$, verifying the survival of agroinfiltrated tissue (data not shown). The host reaction and TRV-DsRed spread observed in cvs. Russet Burbank and Bintje following agroinfection was identical to that observed following mechanical infection (Fig. 3A). Analysis of infiltrated Bintje leaf tissue at 4 dpi revealed DsRed fluorescence in several cells, indicating initial TRV replication before cell death occurred (Fig. 3B). In contrast, no DsRed expression could be observed at any time after TRV-DsRed agroinfiltration in Saturna leaves. The infiltrated leaf tissue displayed necrosis and cell death at $7 \mathrm{dpi}$ (Fig. 3A). This demonstrated that, in Saturna, constitutive expression of both viral RNAs in a multitude of leaf cells induced HR-like tissue necrosis in addition to the ER reaction.

\section{K-PpK20 is the elicitor \\ of ER- and HR-mediated TRV resistance in potato.}

The results described above led to the hypothesis that the resistance is inherited monogenically and, therefore, one viral gene should represent the elicitor of these two newly identified resistance responses to mechanical TRV infection in Bintje and Saturna. In order to allocate the elicitor gene to one of the two TRV genome segments, we repeated the agroinfection only with pTRV1 and observed similar host reaction in all three cultivars (data not shown). Thus, the number of possible candidates could be reduced to the four RNA-1-encoded genes. Initially, TRV RNA-1 with a deleted silencing suppressor gene (pTRV1- $\Delta 16 \mathrm{~K}$ ) was produced and used for agroinfection. From the work of Liu and associates (2002a), it was known that, without the silencing suppressor protein, green fluorescent protein (GFP)-expressing TRV replicates poorly and is unable to produce infection foci visible under UV illumination in $N$. tabacum plants. However, it was anticipated that the virus helicase and polymerase proteins were translated and that initial replication and the production of subgenomic 29K RNA started before RNA silencing shuts off, or at least downregulates the replication. Initially, pTRV1- $\Delta 16 \mathrm{~K}$ was used together with pTRV2-DsRed (TRV- $\Delta 16 \mathrm{~K}$-DsRed) for agroinfection of 4-week-old $N$. benthamiana in direct comparison with TRV-DsRed. DsRed fluorescence was observed in FM (Fig. 3B). As expected, the deletion of 16K led to retarded movement and DsRed fluorescence could be detected in only a few connected cells until $5 \mathrm{dpi}$. Strong decrease of fluorescence was monitored at 7 to $9 \mathrm{dpi}$, suggesting that RNA silencing downregulates virus replication (data not shown). As expected, leaf infiltration with TRV- $\Delta 16 \mathrm{~K}$-DsRed did not induce strong necrotic host reaction compared with infection with wild-type RNA-1 in cv. Russet Burbank. Only single, weakly red fluorescing cells were detectable in the agroinfiltrated leaf tissue at 4 dpi (Fig. 3B), demonstrating virus replication (RNA-1 and -2). In contrast, TRV- $\Delta 16 \mathrm{~K}-\mathrm{DsRed}$ agroinfection in Saturna and Bintje both resulted in hypersensitive host response leading to dead necrotic tissue clearly visible at 7 dpi (Fig. 3A). DsRed fluorescence, however, was seen only in Bintje leaf tissue at 4 dpi (before cell death occurred), but not in Saturna (Fig. 3B), giving another indication for the ER resistance hypothesis. As a control, single agroinfiltration with pTRV2-DsRed alone did not show any fluorescence, indicating that $35 \mathrm{~S}$ transcripts of RNA-2 are not translated in detectable quantities of DsRed without the presence of RNA-1 (data not shown).

Subsequently, pTRV1- $\Delta 29 \mathrm{~K}$ was generated and used for agroinfection together with pTRV2-DsRed (TRV- $\Delta 29 \mathrm{~K}$ DsRed), initially in $N$. benthamiana. Fluorescence of only single cells, produced by RNA-2-encoded DsRed expression (Fig. $3 \mathrm{~B}$ ), and the lack of viral spread suggested that the movement function was strongly reduced if not completely inhibited. In leaves of all three cultivars, viral replication was detected within 5 dpi but restricted to several single cells in the infiltrated patch (Fig. 3B). The $29 \mathrm{~K}$ deletion allowed the virus to replicate even in cells of cv. Saturna. The non-occurrence of necrotic host response in each cultivar tested gave strong evidence for $29 \mathrm{~K}$ elicitor function in both resistant cultivars (Fig. $3 \mathrm{~A}$ ); however, the possibility that other viral factors are necessary for the $29 \mathrm{~K}$ elicitor function could not be excluded.

Therefore, two additional experimental approaches were used to demonstrate that the MP of TRV PpK20, without the presence of other TRV-encoded proteins and in the absence of virus replication, represents the elicitor in potato cvs. Bintje and Saturna. First, agroinfiltration was used for 35S-driven expression of the single $29 \mathrm{~K}$ ORF in potato leaf tissue. For this

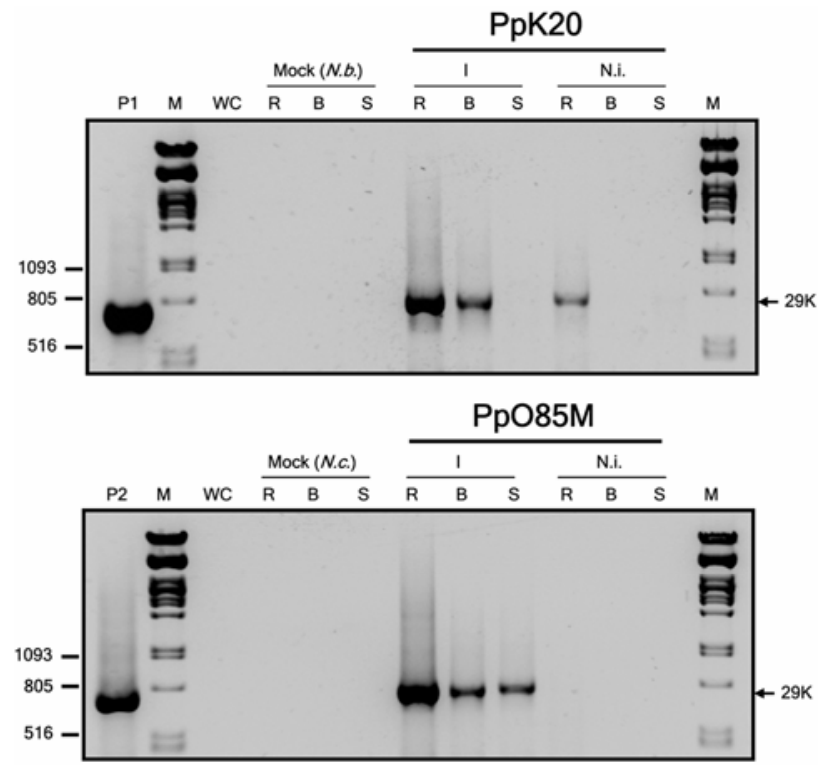

Fig. 2. Reverse-transcriptase polymerase chain reaction detection of RNA-1 in mechanically inoculated leaves at 4 days postinoculation (dpi) (I) and noninoculated leaves at 30 dpi (N.i.) of potato cvs. Russet Burbank (R), Bintje (B), and Saturna (S) with Tobacco rattle virus (TRV) isolate PpK20 (upper panel) and PpO85M (lower panel) using 29-kDa protein (29K) open reading frame specific primers. Total RNA from systemic PpK20-infected N. benthamiana (P1) and PpO85M-infected $N$. clevelandii leaves (P2) were used as positive controls. N.b. and N.c. are RNA samples from noninoculated N. benthamiana and $N$. clevelandii leaves, respectively; WC: water control. The expected position for $29 \mathrm{~K}$ amplification product ( $756 \mathrm{bp}$ ) is indicated. 
purpose, the PpK20 29K ORF was PCR amplified, cloned in pBIN61S under control of Cauliflower mosaic virus 35S promoter $(35 \mathrm{~S}-29 \mathrm{~K})$, and used in a transient agroexpression assay to test its ability to induce HR-like cell death or ER. As control constructs, 35S-empty and 35S-16K were used. As expected from the deletion mutants analysis, leaf tissue necrosis was observed in Bintje and Saturna leaves but not in Russet Burbank leaves at 5 dpi only when $35 \mathrm{~S}-29 \mathrm{~K}$ was infiltrated, whereas no necrosis could be observed with either $35 \mathrm{~S}$-empty or $35 \mathrm{~S}-16 \mathrm{~K}$ in any of the three cultivars used (Fig. 4A). A nontranslatable $29 \mathrm{~K}$ gene (35S-29K-ntr), which did not induce necrosis in any of the tested cultivars by means of agroexpression (Fig. 4A), was used to show that $29 \mathrm{~K}$ protein-not the mRNA - is necessary for this function. RT-PCR detection of $29 \mathrm{~K}-\mathrm{ntr}$ in total nu- cleic acid extracts from agroinfiltrated leaf patches, pretreated with DNase I, was carried out to prove that transcripts were produced (data not shown).

Subsequently, plant viral expression vector based on Potato virus $X$ (PVX) was used to express $29 \mathrm{~K}-\mathrm{PpK} 20$. To test susceptibility of all three cultivars to PVX, PVX-expressing DsRed (pPVX201-optRed, supplied by E. Maiss) was propagated in $N$. benthamiana plants and infected leaf sap was mechanically inoculated to potato leaves. At $10 \mathrm{dpi}$, the inoculated leaf was removed and examined for DsRed expression using FM. In all three cultivars, strong DsRed fluorescence could be detected and no resistance host reaction was observed indicating infection with PVX (data not shown). Subsequently, 35S-PVX in binary vector (pGr106, kindly supplied by D.

A

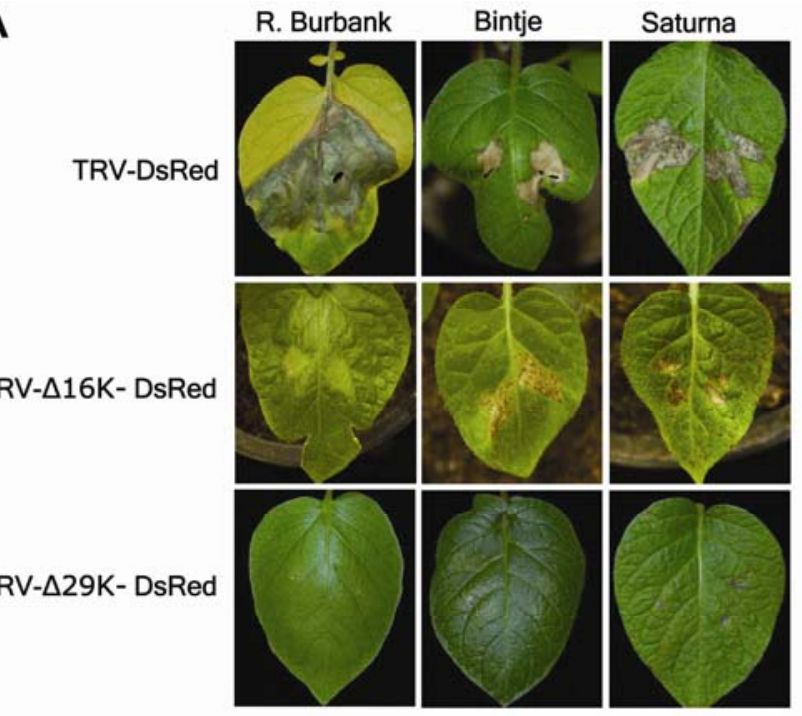

B
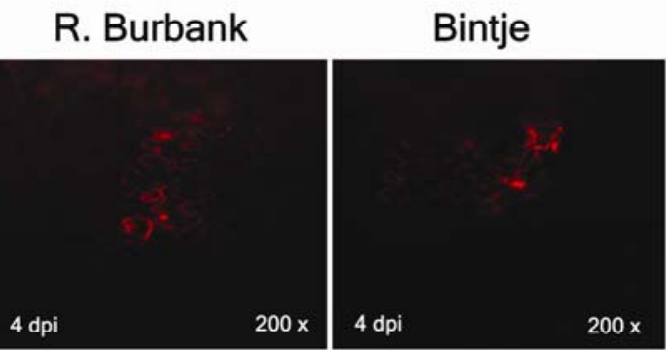

Saturna

N. benthamiana

TRV-DsRed

TRV- $\Delta 16 \mathrm{~K}-\mathrm{DsRed}$
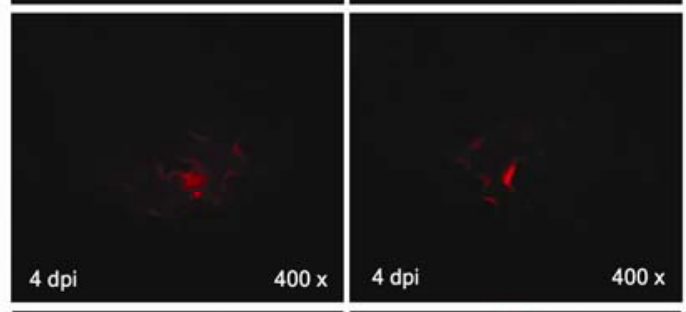

$5 \mathrm{dpi}$

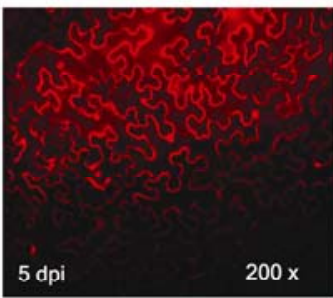

TRV- $\Delta 29 \mathrm{~K}-\mathrm{DsRed}$
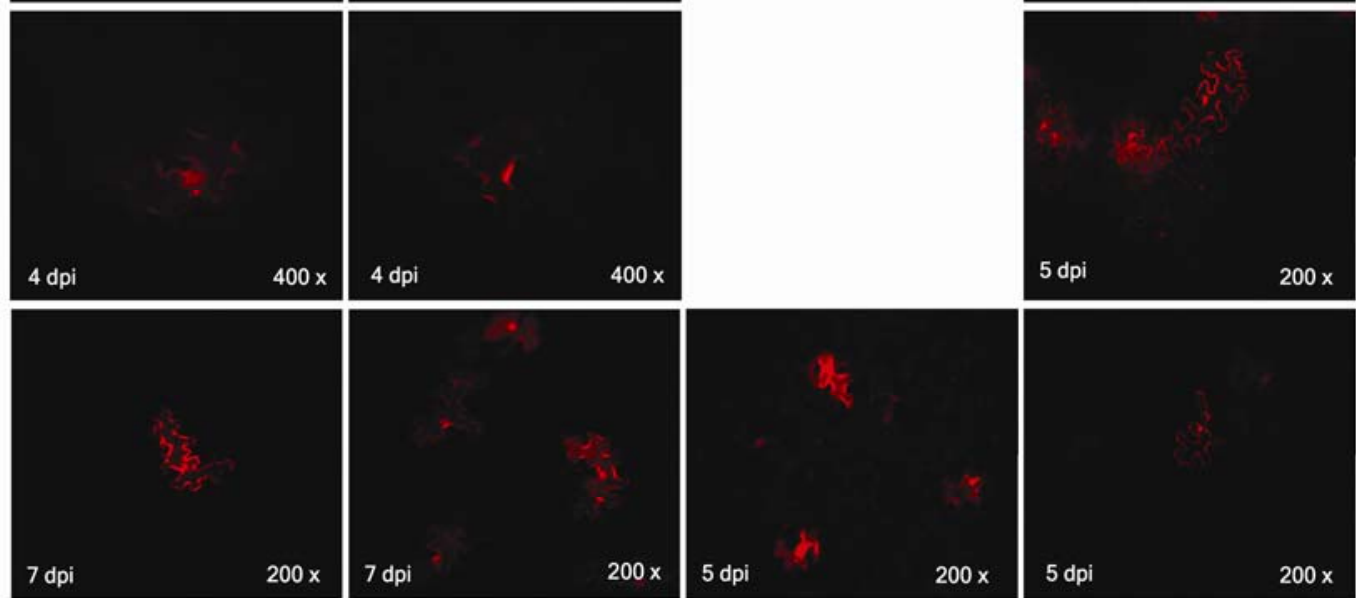

Fig. 3. Leaf-agroinfection of potato cvs. Russet Burbank, Bintje, and Saturna. A, Host response of leaf tissue (7 days postinoculation) agroinfected with Tobacco rattle virus (TRV)-DsRed, $-\Delta 16 \mathrm{~K}-\mathrm{DsRed}$, and $-\Delta 29 \mathrm{~K}$-DsRed. B, Corresponding photos of epifluorescence microscopy DsRed analysis in comparison with agroinfiltrated leaves of Nicotiana benthamiana. Agrobacterium tumefaciens cultures were infiltrated at cell density of $3.2 \times 10^{4}$ cells $/ \mathrm{ml}$. 
Baulcombe) was used for the generation of 35S-PVX-29K and used for agroinoculation of potato cultivars. At 5 dpi, HR-like necrosis was observed in the infiltrated leaves of both cvs. Bintje and Saturna, but not in cv. Russet Burbank (Fig. 4B), showing that HR-like necrosis is elicited by TRV 29K-PpK20 expressed from another potato-infecting virus. PVX replication (35S-PVX and 35S-PVX-29K) was proven by immunodetection of PVX-encoded CP in Russet Burbank leaves (Supplementary Fig. 1).

\section{Mechanical inoculation}

of TRV isolate PpO85M induces cell death in cv. Saturna.

Recently, Robinson (2004) reported the occurrence of a TRV isolate $(\mathrm{PpO} 85 \mathrm{M})$ which was able to overcome the spraing resistance in Bintje but not in Saturna by means of nematodemediated infection. This prompted us to analyze the host reaction of the different resistance sources following mechanical infection with PpO85M (provided by D. J. Robinson). TRV PpO85M (RNA-1 and -2) was used for mechanical inoculation of leaves of all three potato cultivars. The host reaction obtained in PpO85M-infected Russet Burbank leaves was comparable with PpK20 infection (Fig. 5A). Interestingly, RNA-1 and -2 could not be detected by means of RT-PCR in noninoculated leaves within 45 dpi (Fig. 2) (RNA-2, data not shown), suggesting that cv. Russet Burbank limited or at least delayed the spread of this isolate. The host reaction observed in PpO85Minoculated Bintje leaves was comparable with the HR-like observed after PpK20 infection. We expected that an isolate which can induce tuber spraing should be able to spread from the infection site; however, neither enlargement of the necrotic
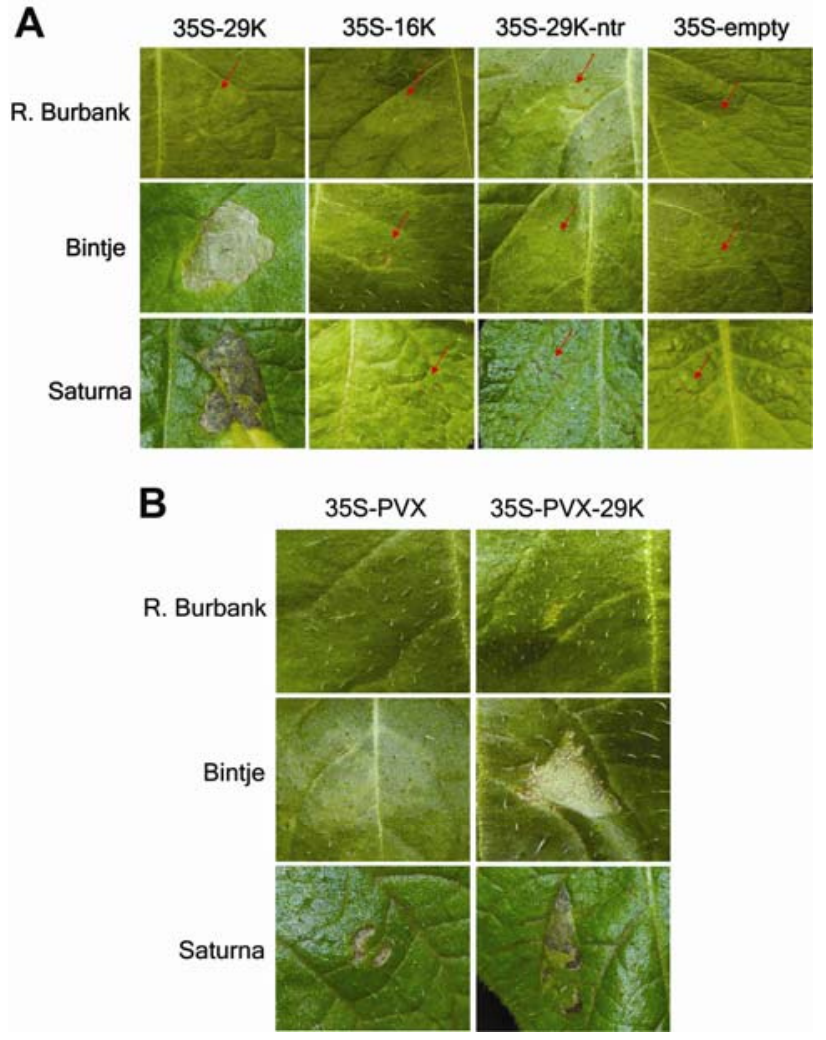

Fig. 4. Tobacco rattle virus (TRV)-PpK20 29-kDa protein (29K) elicits hypersensitive and extreme resistance response without other TRV-encoded proteins or replication. Leaf sections of potato cvs. Russet Burbank, Bintje, and Saturna infiltrated with Agrobacterium tumefaciens $\left(3.2 \times 10^{4}\right.$ cells/ml) transiently expressing A, 35S-29K, 35S-16K, 35S-29K-ntr, or 35S-empty control; B, Potato virus X (PVX)-29K (pGr106-29K) or pPVX (pGr106). Photographs in A and B were taken at 7 days postinoculation. lesions nor systemic infection (RT-PCR) were detected in PpO85M-infected Bintje plants (Figs. 2 and 5A). Although PpO85M induced HR-like cell-death in cv. Saturna and both RNA-1 and -2 could be detected by RT-PCR in inoculated leaves, systemic spread was not observed (Fig. 2) (RNA-2, data not shown). Viral spread and expression of HR-like response did not seem to correlate with the findings of spraing induction in the host-pathogen interactions Russet Burbank-PpK20 and Bintje-PpO85M; therefore, these findings prompted us to analyze the $a v r$ gene functions of isolate PpO85M.

\section{Transient agroexpression}

of 29K-PpO85M does not induce cell death in Bintje leaves.

PpO85M 29K ORF was cloned into pBIN61S to produce 35S-29K-PpO85M. The subsequent transient expression in leaves of all three cultivars analyzed in this study led to the

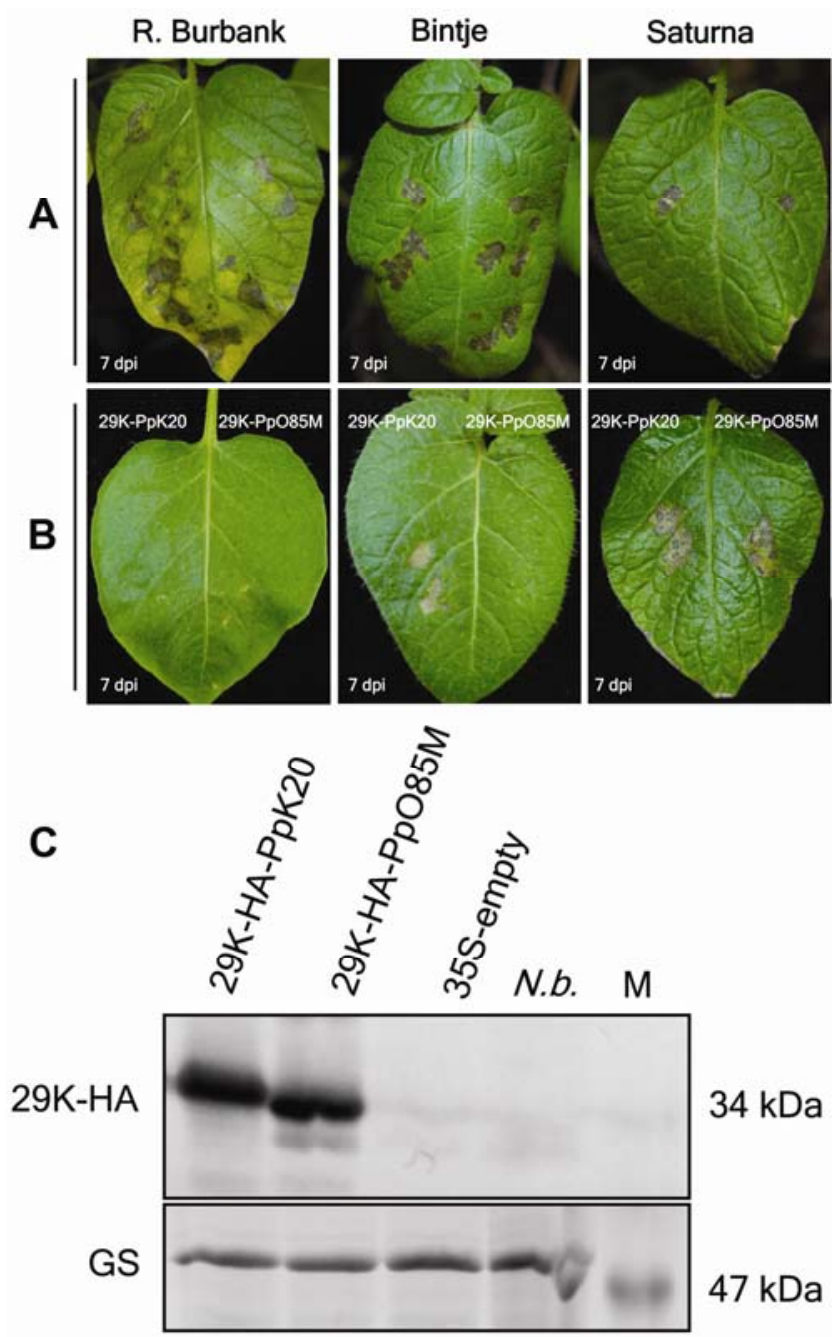

Fig. 5. Host response of Russet Burbank, Bintje, and Saturna leaves mechanically inoculated with Tobacco rattle virus (TRV) isolate $\mathrm{PpO} 85 \mathrm{M}$ and following agroexpression of 29-kDa protein (29K)-PpO85M. A, Leaf host response at 7 days postinoculation (dpi) following mechanical inoculation with TRV PpO85M-infected Nicotiana clevelandii leaf sap. B, Host response of leaves (7 dpi) agroinfected with $29 \mathrm{~K}-\mathrm{PpO} 85 \mathrm{M}$ open reading frame (right leaf half) compared with agroinfiltration with $29 \mathrm{~K}-\mathrm{PpK} 20$ (left leaf half). C, 29K-haemagglutinin (HA): HA immunodetection of TRV $29 \mathrm{~K}$ in total protein extracts of $N$. benthamiana leaf tissue (4 dpi) infiltrated with $35 \mathrm{~S}$-driven constructs, transiently expressing HA-tagged $29 \mathrm{~K}$ of isolate PpK20 (29K-HA-PpK20) and isolate PpO85M (29K-HAPpO85M). Untreated (N.b.) and pBIN61S empty-vector-infiltrated leaf tissue (35S-empty) served as controls; GS: gel staining; M: marker proteins of 34 and $47 \mathrm{kDa}$, respectively. 
following observations. As expected, agroexpression of $35 \mathrm{~S}$ 29K-PpO85M did not induce cell death in either cv. Bintje or cv. Russet Burbank (Fig. 5B). In cv. Saturna, however, an HRlike response comparable with constitutive 29K-PpK20 expression could be observed.

\section{Evidence for expression TRV 29K protein in agroinfiltrated leaf tissue.}

To demonstrate the expression of 29K-PpK20 and -PpO85M, both ORFs were translationally fused at the C-terminus with haemagglutinin (HA) tag, cloned into pBIN61S (35S-29KHA-PpK20 and -PpO85M, respectively) and used for transient agroexpression $\left(\mathrm{OD}_{600}=1\right)$ in $N$. benthamiana leaf tissue. At 4 dpi, total protein extracts were separated by gel electrophoresis and subjected to immunodetection of HA (Fig. 5C). The expression of HA-tagged $29 \mathrm{~K}$ from each isolate was clearly visible compared with protein extracts from untreated and empty-vector-infiltrated $N$. benthamiana leaf tissue. In order to prove that the $29 \mathrm{~K} \mathrm{HA}$ tag had no influence on the host reaction in the bioassay, 35S-29K-HA-PpK20 and -PpO85M both were used for transient agroexpression in leaves of the three potato cultivars analyzed. Phenotypes were indistinguishable from those induced by untagged $29 \mathrm{~K}$ variants (data not shown).

\section{Sequence comparison \\ of $29 \mathrm{~K}$ proteins encoded by different $\mathrm{TRV}$ isolates.}

To date, four different isolates of TRV RNA-1 have been sequenced entirely (TRV PpK20: accession number AF406990; TRV PpO85M: accession number AJ586803; TRV SYM: accession number D00155; and TRV ORY: accession number AF034622). From TRV isolate PSG, only the 3' approximate $2,077 \mathrm{bp}$ are available, containing the $29 \mathrm{~K}$ ORF (TRV PSG: accession number X03685). These nucleotide sequences display high sequence homology, varying between 92 and $99 \%$ (data not shown). In order to relate differences in $29 \mathrm{~K}$ recognition as $a v r$ gene from isolates PpK20 and PpO85M to sequence variability on the amino acid level, all available TRV 29K sequences were used for ClustalX-based alignment (Supplementary Fig. 2). The detected sequence homology varied between 95 and 100\%. 29K-PpO85M displayed the highest sequence divergence of the five isolates (95 to 98\%) as demonstrated by the outgrouping in the phylogenetic tree. Remarkably, the variable amino acids are spread randomly over the $29 \mathrm{~K}$ ORF, with one cluster in the central region of the protein between amino acid position 100 to 114. Direct comparison between 29K-PpK20 and 29K-PpO85M showed difference in 10 amino acid positions, namely V7A, V29M, K54M, D100E, K109R, R112K, K114M, K149R, P225H, and $\mathrm{N} 247 \mathrm{~K}$.

\section{DISCUSSION}

To date, there have been no clear reports about resistance reactions in potato against TRV which fit into the standard classification of resistance types (Cooper and Jones 1983; Hull 2002) or the nomenclature for potato virus resistance proposed by Valkonen and associates (1996). In a study on susceptibility and resistance of different potato cultivars to infection with two different TRV isolates, we have described, for the first time, host reactions which can be assigned to the categories ER, HR-like, and spreading necrosis, In addition to mechanical leaf infection, agroinfection using infectious TRV cDNA clones containing $16 \mathrm{~K}$ and $29 \mathrm{~K}$ ORF deletions and expressing a fluorescent marker gene (DsRed) allowed us to study the possible underlying pathogen recognition mechanism by comparing the visual and microscopic observations with known examples of plant virus resistance from similar categories. In general, host reaction in potato to virus infection may be temperature dependent or influenced by other environmental conditions. This has been shown in a temperature-dependent HR response to ER resistance against PVX (Adams et al. 1986a) and HR resistance to Potato virus Y (PVY) (Valkonen 1997). In the experiments carried out here, the inoculated plants were kept at a constant temperature of 20 to $22^{\circ} \mathrm{C}$. Whether host responses in the different cultivars vary with temperature remain to be investigated.

Russet Burbank plants reacted with lesions and necrosis spreading to the veins when mechanically infected with TRVPpK20. Under the environmental conditions applied, the plant was unable to prevent systemic infection, as was demonstrated by DsRed fluorescence around the borders of the spreading lesion and, later, in noninoculated leaves. The results of RTPCR detection of RNA-1 and -2 were in accordance with this finding. The observed phenotype strongly resembled the spreading necrosis observed when TRV is mechanically inoculated on N. tabacum (var. White Burley) (Harrison 1970; Harrison and Robinson 1986). Remarkably, the Russet Burbank leaves systemically infected with TRV-PpK20 did not show necrosis like the inoculated leaf, but displayed only a slight mosaic. Infection with only RNA-1 was ruled out, because RNA-2 was detectable by RT-PCR. To our knowledge, there is no host reaction to a virus infecting potato described comparable with the reaction we observed in the system TRV-PpK20 versus Russet Burbank. However, a similar host reaction was observed by Vidal and associates (2002), who transformed potato with $Y-1$ and obtained a phenotype to mechanical infection with PVY consisting of spreading necrosis and systemic mosaic. The constitutive expression of both genome parts in Russet Burbank plants by agroinfection led to a comparable but slightly stronger reaction and faster tissue death, which could be explained by the higher inoculum density applied and higher number of initially infected cells.

The observed host reaction following mechanical inoculation of TRV-PpK20 to leaves of cv. Bintje was similar to HR observed in well-known monogenic antiviral resistance responses in potato species (i.e., $N b$ and $N x$, both conferring HR to PVX [Cockerham 1970] and HR against several potyviruses [Valkonen 1997]. The observation of TRV replication (RTPCR detection and RNA-2-encoded DsRed fluorescence) in inoculated leaf tissue within 5 dpi before occurrence of visible cell death and lesion formation, as well as the lack of systemic virus movement, supports the hypothesis of HR-like resistance response in cv. Bintje.

The observed lack of virus accumulation without the visible formation of lesions or localized cell death (following mechanical inoculation) in the interaction between TRV-PpK20 and plants of cv. Saturna strongly resembled the ER observed in potato carrying the monogenic dominant resistance against PVX (Rxl and Rx2) (Köhm et al. 1993; Ritter et al. 1991). Rxl has been shown to reduce PVX replication strongly on the protoplast level, also affecting the accumulation of co-infecting viruses (Adams et al. 1986b; Bendahmane et al. 1995). Additionally, Gilbert and associates (1998) found evidence that the underlying mechanism might suppress the viability of cells. Our observation of TRV-PpK20 rapid arrest, supported by the inability to detect RNA-1 and -2 by RT-PCR and to detect RNA-2-encoded-DsRed fluorescence, is in full agreement with this typical form of virus resistance in potato (Barker 1996, 1997). Even the observation that $R x l$-mediated resistance is able to induce secondary HR when the CP elicitor of PVX is constitutively expressed (Bendahmane et al. 1999) could be reproduced in our system by transient Agrobacterium-mediated pTRV1 inoculation or expression (transient or virus vector 
based) of the PpK20 elicitor molecule 29K. This demonstrates that, like $R x 1$, the TRV resistance in cv. Saturna possesses the potential to induce secondary HR. It may be concluded that constitutive agroexpression allows replication and subgenomic RNA synthesis to a level sufficient to translate $29 \mathrm{~K}$ in quantities required for visible cell death elicitation.

Our observation of resistance reaction in cv. Saturna, however, contrasts to the reaction observed in PVY-inoculated potato carrying the $R y_{\text {sto }}$ gene (Ross 1986), despite the fact that $R y_{\text {sto }}$ is classified into the ER category, too (Valkonen 1994). In that system, PVY is able to replicate in initially infected cells and move to adjacent cells before cell death and virus spread is stopped (Hinrichs et al. 1998), indicating a resistance mechanism different from $R x 1$ and TRV resistance in Saturna plants. The finding that Saturna reacts to the mechanical PpK20 infection with ER response despite producing HR-like necrotic lesions when leaves are mechanically inoculated with the isolate $\mathrm{PpO} 85 \mathrm{M}$ is remarkable and unprecedented. However, the resistance in Saturna seems to be able to limit both isolates PpK20 to the initially infected cell and PpO85M after having spread to several layers of parenchyma cells, as supported by the results of RT-PCR RNA-1 detection. To our knowledge, this is the first report of a resistance response in potato displaying isolate-specific ER and HR-like, giving additional support for a connection of these two resistance classes. In the case of $R x 1$, only a resistance-breaking PVX isolate $\mathrm{HB}$ has been reported (Kavanagh et al. 1992), but no isolate which induces HR. In soybean, a single dominant resistance $R s v-1$ to Soybean mosaic virus has been reported, which reacts as isolate specific with ER or spreading necrosis (Hajimorad and Hill 2001; Lim 1985).

Our goal was to identify the $a v r$ gene product of TRVPpK20 in two potato cultivars displaying resistance responses and inhibiting virus replication (Saturna) or restricting virus movement (Bintje) through the construction and agroinfection of TRV- $\Delta 16 \mathrm{~K}$-DsRed and $-\Delta 29 \mathrm{~K}-\mathrm{DsRed}$. Remarkably, the pTRV- $\Delta 16 \mathrm{~K}$ mutant induced no necrosis in Russet Burbank leaves, indicating that the spreading necrosis observed following the TRV-1 wild type might be induced by non-silencingaffected replication or significant virus movement. The nonoccurrence of necrosis in TRV- $\Delta 29 \mathrm{~K}$-DsRed agroinoculated Russet Burbank leaves, together with the finding that transient $29 \mathrm{~K}$ expression provokes no visible host reaction, leads to the conclusion that the spreading necrosis may be induced by the moving virus, probably as ribonucleoprotein (virus RNA in association with 29K). Single-cell DsRed expression observed in Bintje following infiltration with the $16 \mathrm{~K}$-deletion mutant virus was comparable with that observed in $N$. benthamiana, and the HR-like host reaction was not as pronounced as when induced by wild-type PpK20 infection. Possibly due to RNA silencing, the $29 \mathrm{~K}$ elicitor expression level was impaired, which might have affected the strength and speed of the host reaction. Thus, in all three host genotypes, $16 \mathrm{~K}$ was excluded as an elicitor candidate.

The observation of TRV- $\Delta 29 \mathrm{~K}-\mathrm{DsR}$ ed replication and nonoccurrence of cell death in both resistant cvs. Bintje and Saturna leaves is an indication that $29 \mathrm{~K}$ exhibits the function as an elicitor and was consistent with the observation of cell death following constitutive $29 \mathrm{~K}$ agroexpression and PVXbased expression. Therefore, the results provide strong evidence that the TRV-29K protein represents the elicitor protein of incompatible interactions in the systems TRV-PpK20-Bintje TRV-PpK20-Saturna, and TRV-PpO85M-Saturna. The function of $29 \mathrm{~K}$ in the TRV life cycle is to mediate movement in compatible interactions (Ziegler-Graff et al. 1991). Our results obtained through agroinfection experiments using TRV- $\Delta 29 \mathrm{~K}-$ DsRed in N. benthamiana showed that TRV-encoded fluores- cence was restricted to single cells, supporting the previous finding of TRV $29 \mathrm{~K}$ movement requirement. At present, we do not know whether the genetic basis for resistance in cvs. Bintje and Saturna is inherited by the same factor or factors, possibly with different allelic compositions leading to a variable gene dosage effect, or by different genes. Therefore, we cannot state whether the $29 \mathrm{~K}$ is the elicitor of one single or two different resistances. The finding that $29 \mathrm{~K}$ proteins from isolates PpK20 and PpO85M analyzed in this study both trigger HR-like cell death in cv. Saturna but, in contrast, only PpK20-encoded 29K elicits cell death in cv. Bintje, provided a first indication that the resistance factors might be different. The differences between PpO85M and PpK20 29K comprise 10 amino acid exchanges uniformly distributed throughout the protein sequence; however, until now, none of these changes can be attributed to the different biological effects observed. Thus, we cannot state whether it is only a domain or the entire protein that is necessary to trigger the host resistance response.

Cultivars with known reaction in respect to spraing have been chosen in this study to elucidate whether there is any correlation between the resistance to spraing by natural nematodemediated infection and the host resistance types induced through leaf-inoculation with TRV. Robinson (2004) investigated nematode-mediated infection of cvs. Bintje and Saturna (used in our study) with PpK20 and PpO85M and, in the case of PpK20, did not observe the occurrence of spraing. We initially assumed that the spreading necrosis in leaves of cv. Russet Burbank might correlate with the observation of necrotic rings and arcs in the tuber flesh. This presumption was not applicable to the leaf reaction elicited by isolate PpO85M. However, we observed a negative correlation of the cultivars' ability to recognize the $29 \mathrm{~K}$ of a particular isolate as an $a v r$ gene (when constitutively expressed) and to induce HR-like cell-death with Robinson's spraing observations following natural nematode-mediated infection. To finally prove the hypothesis that resistance to spraing requires the recognition of the $a v r$ gene product, it will be necessary to construct PpK20 and PpO85M 29K chimeras and apply them in nematode-mediated infection experiments. Nevertheless, the ER resistance detected in cv. Saturna seems to be of high practical value to control TRV, because of its effectivity against two isolates displaying highly variable $29 \mathrm{~K}$ elicitor proteins. It remains to be tested whether the resistance is elicited by $29 \mathrm{~K}$ proteins derived from other known TRV isolates. Agrobacterium-mediated transient expression of the resistance elicitor will provide an excellent tool to screen crossing populations because it will yield more reliable information, much faster, about the susceptibility of breeding lines against TRV infection than resistance assessment in the field in natural infested soils.

\section{MATERIALS AND METHODS}

\section{Growth and propagation of plant material.}

Potato cvs. Russet Burbank, Bintje (Bioplant, Ebstorf, Germany), and Saturna (Saka-Ragis, Windeby) were propagated in vitro following Hussey and Stacey (1981) and Zobayed and associates (2001), except that $0.02 \mathrm{M}$ silver thiosulfate solution was added to the agar medium to reduce the effect of ethylene. Cultures were kept in a growth chamber at $20^{\circ} \mathrm{C}$ under coolwhite fluorescent lamps (photosynthetic photon flux $=100 \mu \mathrm{E}$ $\mathrm{s}^{-1} \mathrm{~m}^{-2}$ ) on a 16-h photoperiod, acclimatized as described (Valkonen et al. 1991). Plants were transferred into 15-cmdiameter plastic pots and kept in a growth chamber set for a 16-h day, with a light intensity of $150 \mu \mathrm{E} \mathrm{s}^{-1} \mathrm{~m}^{-2}$ at 20 to $22^{\circ} \mathrm{C}$ and humidity between 60 to $70 \%$. Two weeks later, plants were transferred into a glasshouse with day length of $14 \mathrm{~h}$ supplemented with artificial light. 
Virus isolates.

An M-type TRV isolate PpO85M (RNA-1 accession number AJ586803) (Overloon, The Netherlands) (Robinson 2004) was propagated on $N$. clevelandii. DsRed-expressing TRV (TRVDsRed) for mechanical inoculation was obtained from pTRV1 plus pTRV2-DsRed-agroinfected $N$. benthamiana plants.

\section{Viral full-length clones.}

The $2 \times 35 \mathrm{~S}$ promoter-driven infectious full-length cDNA clone of TRV RNA-1 isolate PpK20 (complete virus sequence accession number AF406990) in a binary vector for use in agroinfection (pTRV1) and the RNA-2-based virus-induced gene-silencing vector pTRV2 (pYL156) first were described by Liu and associates (2002b). Plasmid pK20GFPc was described by MacFarlane and Popovich (2000). The binary 35SPVX plant expression vector (pGr106) has been described (Angell and Baulcombe 1997; Lu et al. 2003). PVX vector expressing DsRed (pPVX201-optRed) has been described previously (Dietrich and Maiss 2002).

\section{Construction of TRV mutants.}

Standard recombinant DNA techniques used were performed according to Sambrook and associates (1989). pTRV1- $\Delta 16 \mathrm{~K}$ was constructed by deleting the $16 \mathrm{~K}$ ORF from pTRV1 as described previously (Liu et al. 2002a). To generate the 35Sdriven cDNA clone of TRV RNA-2 expressing the CP ORF and DsRed-1 under control of the subgenomic promoter ( $\mathrm{sgPr}$ ) of the PEBV CP gene for agroinfection experiments, an AatII$K p n I$ fragment containing sgPr, GFP, and part of the TRV 3' noncoding region from plasmid $\mathrm{pK} 20 \mathrm{GFPc}$ was cloned into pYL156, replacing the MCS of the virus-induced gene-silencing vector. Thereby, the $\mathrm{T} 7$ was replaced by a $2 \times 35 \mathrm{~S}$ promoter and the cDNA clone was rendered suitable for agroinfection experiments. This intermediate plasmid (pYL156-GFP) was tested for infectivity and GFP expression together with pTRV1. GFP expression in potato leaves was low (data not shown); therefore, DsRed-1 (pDsRed-C1; Clontech, Palo Alto, CA, U.S.A.) coding sequence was PCR reamplified, and $B s p H I$ and EcoRI flanking restriction sites were introduced. The GFP ORF in pYL156-GFP was replaced using NcoI and EcoRI. The resulting plasmid pTRV2-DsRed together with pTRV1 was tested for infectivity and DsRed fluorescence by means of leaf agroinfiltration in $N$. benthamiana plants. In order to delete the 29K ORF from the RNA-1 cDNA clone, an AvrII (nucleotide 3,234)-SnaBI (nucleotide 6,774) subclone had to be generated from pTRV1. In this subclone, the $29 \mathrm{~K}$ ORF (nucleotides 5,328 to 6,083) was almost completely removed by digestion with BstEII (nucleotide 5,346) and NarI (nucleotide 5,871), followed by Klenow fill-in reaction and subsequent religation. Backcloning of the AvrII-SnaBI fragment resulted in pTRV $1-\triangle 29 \mathrm{~K}$. This led to a shortened $29 \mathrm{~K}$ ORF, consisting of seven $29 \mathrm{~K}$-derived amino acids plus seven nonviral amino acids resulting from the introduced frame shift.

\section{pGr106-29K-PpK20.}

For PVX-mediated expression of $29 \mathrm{~K}$ of TRV-PpK20, the 29K ORF was PCR amplified, supplied with flanking restriction sites ClaI and SalI, and cloned into pGr106 under control of the doubled sgPr of PVX CP-gene (pGr106-29K-PpK20), and the insert was sequence verified.

\section{Plasmids for transient agroexpression.}

TRV-encoded proteins and DsRed-1 were agroexpressed from pBIN61S (Silhavy et al. 2002) under control of 2x35S promoter and polyA-terminator after RT-PCR reamplification from cDNA clones or total RNA preparations (RNeasy; Qiagen, Hilden, Germany) from $N$. benthamiana and $N$. clevelandii leaves infected with TRV isolates PpK20 and PpO85M, respectively. DsRed-1 ORF was PCR reamplified from pDsRed$\mathrm{C} 1$, cloned, and produced 35S-DsRed. All virus genes were PCR or RT-PCR amplified: PpK20-16K ORF was PCR supplied with flanking restriction sites (SacI-XbaI) and cloned into pBIN61S (35S-16K). 29K-PpK20 and -PpO85M (756 bp; nucleotides 5,328 to 6,083 in accession number AF406990 and nucleotides 5,154 to 5,909 in accession number AJ586803) cloned into pBIN61S were named 35S-29K-PpK20 and 35S$29 \mathrm{~K}-\mathrm{PpO} 85 \mathrm{M}$. A nontranslatable variant of $29 \mathrm{~K}-\mathrm{PpK} 20$ was generated by digesting the $29 \mathrm{~K}$ ORF with BstEII with subsequent Klenow fill-in and religation, leading to a frame-shift at amino acid 8 and a stop codon at amino acid 10. To exclude the translation of a shortened protein translated from internal initiation of the ribosomes, the $29 \mathrm{~K}$ ORF internal XhoI was cut, filled, and religated, leading to an additional frame-shift at amino acid 122 and an additional stop codon at amino acid 127. Backcloning of this nontranslatable $29 \mathrm{~K}$ mutant gene into pBIN61S led to 35S-29K-ntr-PpK20. All inserts in clones of TRV-derived PCR fragments were sequence verified using standard primers. Sequencing reactions were carried out by MWG, Martinsried, Germany. For 29K immunodetection, 29K-PpK20 and -PpO85M were C-terminally fused with an HA affinity tag (YPYDVPDYA). This was achieved by inserting the HA coding sequence into the lower $29 \mathrm{~K}$ PCR primer in frame with $29 \mathrm{~K}$-specific nucleotides. The resulting binary vectors were named 35S-29K-HA-PpK20 and -PpO85M, respectively. For agroinfection of viral full-length clones and Agrobacteriummediated transient expression assays, A. tumefaciens strains C58C1 (pGV2260) for TRV clones and LBA4404 (pAL4404) for PVX clones were applied as described by Voinnet and associates $(2000)$ at a cell density of $3.2 \times 10^{4}$ cells $/ \mathrm{ml}(1: 250$ dilution of $\mathrm{OD}_{600}=1$ ). For TRV infections, separated cultures containing pTRV1 and pTRV2-DsRed or its derived mutants were mixed in a 1:1 ratio (Ratcliff et al. 2001).

\section{Mechanical inoculation with viruses.}

Systemically infected tobacco leaf samples with TRVDsRed and TRV-PpO85M were collected in liquid $\mathrm{N}_{2}$ and stored at $-80^{\circ} \mathrm{C}$ as an inoculum source for potato inoculation. For mechanical infection of leaves of 4-week-old potato plants, plant sap 1/25 diluted in HEPES (0.03 M, pH 7.0) was used.

\section{Immunodetection of 29K-HA.}

Total leaf protein extracts from agroinfiltrated leaf patches were obtained by grinding $100 \mathrm{mg}$ of $\mathrm{N}_{2}$-frozen leaf-samples with $300 \mu \mathrm{l}$ of sample buffer (4 M urea, $4 \%$ sodium dodecyl sulfate, $0.2 \mathrm{M}$ dithiothreitol, $20 \%$ glycerol, $0.2 \mathrm{M}$ Tris $/ \mathrm{HCl}$ [pH 6.8], 0.04 bromophenolblue). Extracted samples $(5 \mu \mathrm{l}$ each) were separated by sodium dodecyl sulfate polyacrylamide gel electrophoresis and electroblotted on polyvinylidene diflouride membrane (Roche, Mannheim, Germany). Membrane was incubated overnight at $4{ }^{\circ} \mathrm{C}$ in blocking buffer (Tris-buffered saline, $0.1 \%$ Tween-20, $2 \%$ skimmed milk) and washed (Trisbuffered saline, $0.1 \%$ Tween-20). 29K-HA was probed with rat monoclonal antibodies (anti-HA high affinity; Roche, 1:800) and anti-rat IgG alkaline phosphatase conjugate (Sigma, 1:7.000). Detection was performed using chromogenic substrates 5-bromo-4-chloro-3-indolyphosphate, p-toluidine salt and nitro blue tetrazolium chloride reagents (Applichem).

\section{RT-PCR detection of TRV in infected potato leaf tissue.}

Total RNA preparations (RNeasy; Qiagen) from TRVinfected potato leaves were used for RT-PCR detection of RNA-1. Specific primers were designed to amplify the $29 \mathrm{~K}$ ORF (756 bp). In order to detect RNA-2, CP gene-specific primers derived from PpK20 sequence were used, amplifying 
the exact 621-bp ORF. For 29K-ntr transcript detection in transient agroexpression assays, total RNA preparations were digested with DNase (RQ1; Promega, Madison, WI, U.S.A.) following the manufacturer's instructions before 29K-specific primers were used in RT-PCR reactions as described above.

\section{Epifluorescence microscopy.}

Spread of TRV-expressing DsRed was detected by epifluorescence microscopy (Leica DMR, Heidelberg, Germany) using specific DsRed filters (Emitter HQ 620/60, Beamsplitter Q 585 LP, and Exciter HQ 565/30). Photographs were taken using a Leica DFC camera, DFC300 FX.

\section{ACKNOWLEDGMENTS}

We are grateful to D. J. Robinson for providing TRV isolate PpO85M, and S. A. MacFarlane for the gift of plasmid pK20GFPc. We acknowledge S. P. Dinesh-Kumar for providing pTRV1 and pTRV2 vectors. We thank R Schuchmann (Bioplant GmbH, Ebstorf, Germany) and SAKA-Ragis Pflanzenzucht GbR (Windeby, Germany) for providing the potato cultivars used in this study. Finally, we would like to acknowledge D. Baulcombe for providing PVX plant expression vector pGR106 and E. Maiss for the DsRed-1expressing PVX variant pPVX201-optRed. This work has been supported by the Scholarship Merit Program, Islamic Development Bank (IDB).

\section{LITERATURE CITED}

Adams, S. E., Jones, R. A. C., and Coutts, R. H. A. 1986a. Effect of temperature on Potato virus $X$ infection in potato cultivars carrying different combinations of hypersensitivity genes. Plant Pathol. 35:517-526.

Adams, S. E., Jones, R. A. C., and Coutts, R. H. A. 1986b. Expression of Potato virus $X$ resistance gene $R x$ in potato leaf protoplasts. J. Gen. Virol. 67:2341-2345.

Angell, S. M., and Baulcombe, D. C. 1997. Consistent gene silencing in transgenic plants expressing a replicating Potato virus $X$ RNA. EMBO (Eur. Mol. Biol. Organ.) J. 16:3675-3684.

Barker, H. 1996. Inheritance of resistance to Potato viruses $Y$ and $A$ in progeny obtained from potato cultivars containing gene $R y$ : Evidence for a new gene for extreme resistance to PVA. Theor. Appl. Genet. 93:710716.

Barker, H. 1997. Extreme resistance to Potato virus $V$ in clones of Solanum tuberosum that are also resistant to Potato viruses $Y$ and A: Evidence for a locus conferring broad-spectrum potyvirus resistance. Theor. Appl. Genet. 95:1258-1262.

Barker, H., and Dale, M. F. B. 2006. Resistance to viruses in potato. Pages 341-366 in: Natural Resistance Mechanisms of Plants to Viruses. G. Loebenstein and J. P. Carr, eds. Springer, Dordrecht, The Netherlands.

Bendahmane, A., Köhm, B. A., Dedi, C., and Baulcombe, D. C. 1995. The coat protein of Potato virus $X$ is a strain-specific elicitor of Rx1-mediated virus resistance in potato. Plant J. 8:933-941.

Bendahmane, A., Kanyuka, K., and Baulcombe, D. C. 1999. The $R x$ gene from potato controls separate virus resistance and cell death responses. Plant Cell 11:781-791.

Cadman, C. H. 1959. Potato stem-mottle disease in Scotland. Eur. Potato J. 2:165-175

Cadman, C. H., and Harrison, B. D. 1959. Studies on the properties of soil-borne viruses of the Tobacco rattle type occurring in Scotland. Ann. Appl. Biol. 47:542-556.

Cockerham, G. 1970. Genetical studies on resistance to Potato viruses $X$ and $Y$. Heredity 25:309-348.

Cooper, J. I., and Jones, A. T. 1983. Responses of plants to viruses: Proposals for the use of terms. Phytopathol. 73:127-128.

Culver, J. N. 1997. Viral avirulence genes. Pages 196-219 in: Plant-Microbe Interactions, Vol. 2. G. Stacey and N. T. Keen, eds. Chapman and Hall, New York.

Dale, M. F. B., and Solomon, R. M. 1988. A glasshouse test to assess the sensitivity of cultivars to Tobacco rattle virus. Ann. Appl. Biol. 112:225-229.

Dale, M. F. B., Robinson, D. J., Griffiths, D. W., Todd, D., and Bain, H. 2000. Effects of tuber-borne M-type strain of Tobacco rattle virus on yield and quality attributes of potato tubers of the cultivar Wilja. Eur. J. Plant Pathol. 106:275-282.

Dietrich, C., and Maiss, E. 2002. Red fluorescent protein DsRed from Discosoma $\mathrm{sp}$. as a reporter protein in higher plants. Biotechniques 32:286-293.

Eibner, R. 1959. Untersuchungen über die 'Eisenfleckigkeit' der Kartoffel. Doctoral dissertation, Justus-Liebig-Universität, Giessen, Germany.
Engsbro, B. 1973. Undersoegelser og forsoeg vedrorende jordbarne vira: I Rattle-virus, fortsatte undersoegelser i kartofler. Tidsskr. Planteavl. 77:103-117.

Gilbert, J., Spillane, C., Kavanagh, T. A., and Baulcombe, D. C. 1998. Elicitation of $R x$-mediated resistance to PVX in potato does not require new RNA synthesis and may involve a latent hypersensitive response. Mol. Plant-Microbe Interact. 11:833-835.

Hajimorad, M. R., and Hill, J. H.. 2001. Rsvl-mediated resistance against Soybean mosaic virus-N is hypersensitive response-independent at inoculation site, but has the potential to initiate a hypersensitive responselike mechanism. Mol. Plant-Microbe Interact. 14:587-598.

Hamilton, W. D. O., and Baulcombe, D. C. 1989. Infectious RNA produced by in vitro transcription of a full-length Tobacco rattle virus RNA-1 cDNA. J. Gen. Virol. 70:963-968.

Hammond-Kosack, K. E., and Jones, J. D. G. 1996. Resistance gene-dependent plant defense responses. Plant Cell 8:1773-1791.

Harrison, B. D. 1968. Reactions of some old and new British potato cultivars to Tobacco rattle virus. Eur. Potato J. 11:165-176.

Harrison, B. D. 1970. Tobacco rattle virus. CMI/AAB Description of Plant Viruses, No. 12. Association of Applied Biologists, Warwick, U.K.

Harrison, B. D., and Robinson, D. J. 1978. The Tobraviruses. Adv. Virus Res. 23:25-77.

Harrison, B. D., and Robinson, D. J. 1986. Tobraviruses. Pages 339-369 in: The Plant Viruses, Vol. 2. M. H. V. van Regenmortel and H. FraenkelConrat, eds. Plenum Press, New York.

Hernández, C., Visser, P. B., Brown, D. J. F., and Bol, J. F. 1997. Transmission of Tobacco rattle virus isolate PpK20 by its nematode vector requires one of the two non-structural genes in the viral RNA 2. J. Gen. Virol. 78:465-467.

Hinrichs, J., Berger, S., and Shaw, J. G. 1998. A hypersensitive responselike mechanism is involved in resistance of potato plants bearing the $R y_{\text {sto }}$ gene to the potyviruses Potato virus $Y$ and Tobacco etch virus. J. Gen. Virol. 79:167-176.

Hull, R. 2002. Matthew's Plant Virology, 4th ed. Academic Press, San Diego, CA, U.S.A.

Hussey, G., and Stacey, N. J. 1981. In vitro propagation of potato (Solanum tuberosum L.). Ann. Bot. 48:787-796.

Kang, B.-C., Yeam, I., and Jahn, M. M. 2005. Genetics of plant virus resistance. Annu. Rev. Phytopathol. 43:581-621.

Kavanagh, T., Goulden, M., Cruz, S. S., Chapman, S., Barker, I., and Baulcombe, D. 1992. Molecular analysis of a resistance-breaking strain of Potato virus X. Virology 189:609-617.

Köhm, B. A., Goulden, M. G., Gilbert, J. E., Kavanagh, T. A., and Baulcombe, D. C. 1993. A Potato virus $X$ resistance gene mediates an induced, nonspecific resistance in protoplasts. Plant Cell 5:913-920.

Lim, S. M., 1985. Resistance to Soybean mosaic virus in soybeans. Phytopathology 75:199-201.

Liu, H., Reavy, B., Swanson, M., and MacFarlane, S. A. 2002a. Functional replacement of the Tobacco rattle virus cysteine-rich protein by pathogenicity proteins from unrelated plant viruses. Virology 298:232-239.

Liu, Y., Schiff, M., Marathe, R., and Dinesh-Kumar, S. P. 2002b. Tobacco Rar1, EDS1 and NPR1/NIM1 like genes are required for $N$-mediated resistance to Tobacco mosaic virus. Plant J. 30:415-429.

Lu, R., Malcuit, I., Moffett, P., Ruiz, M. T., Peart, J., Wu, A. J., Rathjen, J. P., Bendahmane, A., Day, L., and Baulcombe, D. C. 2003. High throughput virus-induced gene silencing implicates heat shock protein 90 in plant disease resistance. EMBO (Eur. Mol. Biol. Organ.) J. 22:5690-5699.

MacFarlane, S. A. 1999. Molecular biology of the tobraviruses. J. Gen. Virol. 80:2799-2807.

MacFarlane, S. A., and Popovich, A. H. 2000. Efficient expression of foreign proteins in roots from tobravirus vectors. Virology 267:29-35.

MacFarlane, S. A., Brown, D. J. F., and Bol, J. F. 1995. The transmission by nematodes of tobraviruses is not determined exclusively by the virus coat protein. Eur. J. Plant Pathol. 101:535-539.

MacFarlane, S. A., Wallis, C. V., and Brown, D. J. F. 1996. Multiple virus genes involved in the nematode transmission of Pea early browning virus. Virology 219:417-422.

Mojtahedi, H., Crosslin, J. M., Santo, G. S., Brown, C. R., and Thomas, P. E. 2001. Pathogenicity of Washington and Oregon isolates of Tobacco rattle virus on potato. Am. J. Potato Res. 78:183-190.

Nimchuk, Z., Eulgem, T., Holt, B. F., III, and Dangl, J. L. 2003. Recognition and response in the plant immune system. Annu. Rev. Genet. 37:579-609.

Ploeg, A. T., Robinson, D. J., and Brown, D. J. F. 1993. RNA-2 of Tobacco rattle virus encodes the determinants of transmissibility by trichodorid vector nematodes. J. Gen. Virol. 74:1463-1466.

Ratcliff, F. G., Hernandez, A. M. M., and Baulcombe, D. C. 2001. Tobacco rattle virus as a vector for analysis of gene function by silencing. Plant J. 25:237-245. 
Reavy, B., Dawson, S., Canto, T., and MacFarlane, S. A. 2004. Heterologous expression of plant virus genes that suppress post-transcriptional gene silencing results in suppression of RNA interference in Drosophila cells. BMC Biotechnol. 4:18.

Ritter, E., Debener, T., Barone, A., Salamini, F., and Gebhardt, C. 1991. RFLP mapping on potato chromosomes of two genes controlling extreme resistance to Potato virus X (PVX). Mol. Gen. Genet. 227:81-85.

Robinson, D. J. 2004. Identification and nucleotide sequence of a Tobacco rattle virus RNA-1 variant that causes spraing disease in potato $\mathrm{cv}$. Bintje. J. Phytopathol. 152:286-290.

Robinson, D. J., and Dale, M. F. B. 1994. Susceptibility, resistance and tolerance of potato cultivars to Tobacco rattle virus infection and spraing disease. Asp. Appl. Biol. 39:61-66.

Ross, H. 1986. Potato breeding-problems and perspectives. in: Advances in Plant Breeding. J. Brandes, R. Bartels, J. Völk, and C. Wetter, eds. J. Plant Breed. (Suppl.) 13. Pual Parey, Berlin and Hamburg, Germany.

Sambrook, J., Fritsch, E. F., and Maniatis, T. 1989. Molecular Cloning: A Laboratory Manual. Cold Spring Harbor Laboratory, Cold Spring Harbor, NY, U.S.A

Silhavy, D., Molnar, A., Lucioli, A., Szittya, G., Hornyik, C., Tavazza, M., and Burgyán, J. 2002. A viral protein suppresses RNA silencing and binds silencing-generated, 21- to 25-nucleotide double-stranded RNAs. EMBO (Eur. Mol. Biol. Organ.) J. 21:3070-3080.

Solomon-Blackburn, R. M., and Barker, H. 2001a. A review of host majorgene resistance to potato viruses $X, Y, A$ and $V$ in potato: Genes, genetics and mapped locations. Heredity 86:8-16.

Solomon-Blackburn, R. M., and Barker, H. 2001b. Breeding virus resistant potatoes (Solanum tuberosum): A review of traditional and molecular approaches Heredity 86:17-35.

Valkonen, J. P. T. 1994. Natural genes and mechanisms for resistance to viruses in cultivated and wild potato species (Solanum spp.). Plant Breed. 112:1-16.

Valkonen, J. P. T. 1997. Novel resistances to four potyviruses in tuberbearing potato species, and temperature-sensitive expression of hypersensitive resistance to Potato virus Y. Ann. Appl. Biol. 130:91-104.

Valkonen, J. P. T., Pehu, E., Jones, M. G. K., and Gibson, R. W. 1991. Resistance in Solanum brevidens to both Potato virus $Y$ and Potato virus $X$ may be associated with slow cell-to-cell spread. J. Gen. Virol. 72:231-236.

Valkonen, J. P. T., Jones, R. A. C., Slack, S. A., and Watanabe, K. N. 1996. Resistance specificities to viruses in potato: Standardisation of nomenclature. Plant Breed. 115:433-438.

Vidal, S., Cabrera, H., Andersson, R. A., Fredriksson, A., and Valkonen, J. 2002. Potato gene $Y-1$ is an $N$ gene homology that confers cell death upon infection with Potato virus $Y$. Mol. Plant-Microbe Interact. 15:717-727.

Voinnet, O., Lederer, C., and Baulcombe, D. C. 2000. A viral movement protein prevents spread of the gene silencing signal in Nicotiana benthamiana. Cell 103:157-167.

Walkinshaw, C. H., and Larson, R. H. 1959. Corky ringspot of potato: A soil-borne virus disease. University of Wisconsin Agriculture Experiment Station Research Bulletin No. 217, Madison, WI, U.S.A..

Xenophontos, S., Robinson, D. J., Dale, M. F. B., and Brown, D. J. F. 1998. Evidence for persistent, symptomless infection of some potato cultivars with Tobacco rattle virus. Potato Res. 41:255-265.

Ziegler-Graff, V., Guilford, P. J., and Baulcombe, D. C. 1991. Tobacco rattle virus RNA-1 $29 \mathrm{~K}$ gene product potentiates viral movement and also affects symptom induction in tobacco. Virology 182:145-155.

Zobayed, S. M. A., Armstrong, J., and Armstrong, W. 2001. Micropropagation of potato: Evaluation of closed, diffusive and forced ventilation on growth and tuberization. Ann. Bot. 87:53-59. 